UDC 616-057: 613.6

DOI: $10.21668 /$ health.risk/2020.3.15.eng

Research article

\title{
INFLUENCE EXERTED BY SOMATIC PATHOLOGY ON RISKS OF OCCUPATIONAL LUNG FIBROSIS IN WORKERS EMPLOYED AT REFRACTORY PRODUCTION
}

\author{
T.Yu. Obukhova ${ }^{1}$, L.N. Budkar', ${ }^{1}$ V.B. Gurvich ${ }^{1}$, \\ S.I. Solodushkin ${ }^{2}$, O.G. Shmonina ${ }^{1}$, E.A. Karpova ${ }^{1}$ \\ ${ }^{1}$ Ekaterinburg Medical Research Center for Prophylaxis and Health Care in Industrial Workers, \\ 12 Moskovskaya Str., Ekaterinburg, 620014, Russian Federation \\ ${ }^{2}$ Ural Federal University named after the first President of Russia B.N. Yeltsin, 51 Lenina Ave., Ekaterinburg, \\ 620075, Russian Federation
}

Occupational lungs and bronchial pathology occurs not only under exposure to dusts, their aerosol structure and aggression, but also depends on individual properties of a body. The latter can determine either increased body resistance or susceptibility to occupational pathology occurrence.

Our research goal was to determine influence exerted by somatic pathology on occupational lung fibrosis occurrence as well as to estimate prevalence of risk factors for cardiovascular and metabolic pathology occurrence in workers employed at refractory production.

At the first stage 449 workers employed at refractory production were examined at a periodical medical examination (PME). Patients' average age was $41.59 \pm 0.45$ and average work experience was $14.47 \pm 0.39$ years. At the second stage 172 workers were examined at an occupational pathology center; 75 out of them were workers who had silicosis and were included into the test group and the remaining 97 workers didn't have any occupational pathology and were included into the reference group. Both groups were comparable as per sex $(p=0.0052)$ and work experience under exposure to dusts $(p=0.862)$

Workers examined at a PME most frequently had overweight and obesity (68\%). Arterial hypertension (AH) prevalence amounted to 19.5\%; carbohydrate metabolism disorders, $19.8 \%$; $48.1 \%$ workers had hypercholesterolemia. Patients with silicosis had certain disorders significantly more frequently than workers with long work experience but without any occupational pathologies; those disorders were AH, cardiac muscle hypertrophy in the left ventricle, ischemic heart disease, heart rate disorders, as well as mixed (obstructive and restrictive) breath mechanics disorders. We determined some factors that authentically produced certain effects on occupational lung fibrosis occurrence in workers employed at refractory production. Median time of silicosis occurrence was significantly shorter (by 11.5 years) among workers with severe AH, arrhythmia (by 13 years), lower hemoglobin in blood (by 11.5 years). Besides, silicosis occurred significantly earlier (by 10.8) among women than among men.

Key words: refractory production, fibrogenic dust, silicosis, somatic pathology, median work experience, arterial hypertension, hypercholesterolemia, obesity, metabolic disorders.

(c) Obukhova T.Yu., Budkar' L.N., Gurvich V.B., Solodushkin S.I., Shmonina O.G., Karpova E.A., 2020

Tat'yana Yu. Obukhova - Candidate of Medical Sciences, Senior researcher at the «Clinic for Occupational Diseases Therapy and Diagnostics»s scientific and production association (e-mail: obuhova@ymrc.ru; tel.: +7 (343) 353-14-70; ORCID: https://orcid.org/0000-0002-7913-5586).

Lyudmila N. Budkar' - Doctor of Medical Sciences, Professor, Research Supervisor of the "Clinic for Occupational Diseases Therapy and Diagnostics» scientific and production association (e-mail: ludanb@ymrc.ru; tel.: +7 (343) 371-87-22; ORCID: https://orcid.org/0000-0003-1154-3329).

Vladimir B. Gurvich - Doctor of Medical Sciences, Research Supervisor of the «Clinic for Occupational Diseases Therapy and Diagnostics» scientific and production association (e-mail: gurvich@ymrc.ru; tel.: +7 (343) 371-87- 54; ORCID: https://orcid.org/0000-0002-6475-7753).

Svyatoslav I. Solodushkin - Candidate of Physical and Mathematical sciences, Associate professor (e-mail: solodushkin_s@mail.ru; tel.: +7 (343) 389-94-67; ORCID: https://orcid.org/0000-0002-1959-5222).

Ol'ga G. Shmonina - Head of the «Clinic for Occupational Diseases Therapy and Diagnostics» scientific and production association (e-mail: shmonina@ymrc.ru; tel.: +7 (343) 371-14-73; ORCID: https://orcid.org/0000-0002-2661-3425).

Elena A. Karpova - Candidate of Medical Sciences, acting as the Head of Clinical and Expert Work Department (e-mail: karpovaea@ymrc.ru; tel.: +7 (343) 371-87-22; ORCID: https://orcid.org/0000-0001-8659-0678). 
Respiratory diseases are among the most significant issues for contemporary occupational medicine as they account for more than one fifth of all the occupational diseases ${ }^{1}$ [1]. Lung diseases with damage to the lungs caused by exposure to industrial aerosols hold the $2^{\text {nd }}$ rank place as per their prevalence in occupational morbidity structure; such diseases result in substantial social and economic losses due to lower working capacity or total loss of it by workers ${ }^{2,3}$. It occurs due to both insufficient control over exposure to industrial dusts under adverse working conditions and late diagnostics of the diseases caused by their long latent period. Dust diseases in the lungs lead to working capacity loss and make patients' life shorter ${ }^{3}[2]$.

At present it is obvious that a nature of pathology developing in the bronchial tubes and lungs, its clinical course and complications are determined not only by dust loads, industrial aerosol structure, and their aggressive properties, but also by individual characteristics of a body including its elevated sensitivity to effects produced by fibrogenic dusts. It can be due to differences in biochemical reactions, in regulation mechanisms of physiological systems, humoral and endocrine factors, and immune reactions of a body. Special significance here belongs to a range of activity for biochemical processes behavior based on genetic polymorphism [3].

Experimental works revealed that silicon dioxide dust caused changes in membrane phospholipids structure with a decrease in amount of phospholipids with unsaturated fatty acids; it resulted in improper membranes penetrability, changes in lipid-dependent enzymes activity, and, consequently, in disorders in metabolic processes in a cell. Chronic introduction of fibrogenic dust into the respiratory organs makes for lipid metabolism disorders.
Contents of all lipid fractions grow together with an increase in lung tissue weight. As per data taken form literature, there are elevated lipid contents in blood of workers who have long contacts with quartz dust, workers with «suspected» silicosis and patients already suffering from the disease ${ }^{3}$.

At present it is beyond any doubts that dust pathology develops in the lungs due to critical mass of dusts being present in the organ $[4,5]$. Pathogenesis of pneumoconiosis and silicosis in particular involves cellular cooperation between macrophages, fibroblasts, and leukocytes, and it stimulates excessive immune system activation thus leading to chronic inflammation development. This inflammation is determined by immunemodulating effects produced by quartz on the immune system. Long-term excessive formation of active oxygen forms is known as oxidative stress that is considered to be the key component in dust pathology development and plays the leading role in pathogenesis of interstitial diseases in the lungs. When dusts enter a human body, oxidative stress occurs prior to silicosis and other dust diseases in the respiratory organs ${ }^{3}$. At the same time fibrogenesis, as a response to damage, occurs via complex cellular interactions that become possible due to specific molecular routes ${ }^{4}$. Pathological process is based on long-term retention of dust particles in the lungs caused by inefficient selfpurification mechanisms of the respiratory tracts. And here different susceptibility can be caused by different self-purification efficiency; thank to it, occupational lung fibrosis develops in different time in different workers even under the same exposure to dust [6].

Development of pathologic process caused by exposure to dust particles and their effects on lung tissue is accompanied with changes in cellular structures of lung tissue,

\footnotetext{
${ }^{1}$ Pilishenko V.A., Glushkova N.Yu., Kurkin D.P. On situation with occupational morbidity in the Russian Federation in 2011: reference collection of analytical data. Moscow, Rospotrebnadzor's Federal Center for Hygiene and Epidemiology Publ., 201, 48 p. (in Russian).

${ }^{2}$ Occupational pathology: the national guide. In: N.F. Izmerov ed. Moscow, GEOTAR-Media Publ., 2011, 784 p. (in Russian).

${ }^{3}$ Occupational diseases of the respiratory organs. The national guide. In: N.S. Izmerov, A.G. Chuchalin eds. Moscow, 2015, 792 p. (in Russian).

${ }^{4}$ Kosov A.I. Clinical and immunologic signs of chronic obstructive pulmonary disease and dust diseases in the respiratory organs: thesis of the dissertation ... for the Doctor of Medical Sciences degree. Samara, 2008, 45 p. (in Russian).
} 
changes in cellular structure of bronchial and alveolar secretion, and changes in immune reactivity [7]. Coniophages death results in aseptic inflammation and its development involves participation of both phagocytes activation products and phagocytes decay products; there is also a drastic increase in synthesis of antiinflammation mediators $[2,8,9]$. At the same time there are research works with data on systemic nature of a body response to a long-term exposure to industrial dusts confirmed by registered morphological changes in various organs [1]. Several experimental works contain data on damage to the kidneys, heart, and vessels as well as on disorders in various metabolic processes in a body $[10,11]$.

Clinic practice shows that risks of occupational diseases are determined by not only hygienic criteria but also hereditary factors, living conditions, nutrition peculiarities, bad habits, and concomitant somatic pathology [12].

As there are unfavorable trends in contemporary society showing an increase in prevalence of risk factors that cause cardiovascular and metabolic pathology such as obesity, carbohydrate and lipid metabolism disorders, and arterial hypertension [13-16], one should assume that somatic pathology can exert its influence on occupational pathology occurrence.

Our research goal was to establish to what extent somatic pathology influenced a period of time during which occupational lung fibrosis developed as well as to assess prevalence of risk factors that could cause cardiovascular and metabolic pathology occurrence in workers employed at refractory production.

Data and methods. Our research had two stages. At the first stage we analyzed prevalence of cardiovascular and metabolic pathology among workers employed at refractory production as per results obtained via periodical medical examinations (PME) according to the Order No. $302 \mathrm{n}^{5}$. At the second stage patients were examined at the clinic of the Occupational Pathology Center and influence exerted by somatic pathology on terms of silicosis occurrence in workers employed at refractory production was analyzed. To do that, we compared median working experience (it is predicted that an occupational disease will occur in a half of workers who reach this length of their working experience) in patients with different somatic pathologies.

449 workers were examined during a PME; their average age was equal to $41.59 \pm 0.5$ (from 18 to 66 ), average working experience at the examined enterprise was equal to $14.47 \pm 0.39$ (from 1 to 43 ). There were 304 males among the examined workers $(67.7 \%)$. The test group included 311 workers with basic occupations existing at fire-clay silica refractory production (mixing rollers operators, grinder operators, press operators, repairmen, and carrier operators) with their average age being $41.51 \pm 0.54$ and average working experience being $14.53 \pm 0.51$. There were 211 males among the examined workers $(69 \%)$. When performing their work tasks, workers were exposed to a set of adverse occupational factors and the basic one was highly fibrogenic dust with crystalline silicon dioxide contents accounting for more than $70 \%$ in its structure $\left(\mathrm{MPC}_{\mathrm{w} . a . a i r}=1 \mathrm{mg} / \mathrm{m}^{3}\right)$. Average group concentration of crystalline silicon dioxide dust in working area air amounted to $1.05 \pm 0.02 \mathrm{mg} / \mathrm{m}^{3}$. The reference group was made up of 53 people (31 of them or $58 \%$ were males) who were not exposed to silicosis-hazardous dust at their workplaces. Average age of people included into the reference group was $44.13 \pm 1.37$ and their average working experience was $16.25 \pm 1.18$ years. Basic occupations in the group were engineers, loader drivers, painters, foremen, sorter operators, and inspectors. Both groups were compa-

\footnotetext{
${ }^{5}$ On approving the list of adverse and (or) hazardous occupational factors and work tasks which require obligatory preliminary and periodical medical examinations and the Procedure for accomplishing obligatory preliminary and perifocal medical examinations of workers employed at workplaces with hard labor and adverse and (or) hazardous working conditions (amended and supplemented): The RF Public Healthcare Ministry Order No. 302n issued in 2011. KonsultantPlus. Available at: http://www.consultant.ru/document/cons_doc_LAW_120902/(04.08.2020) (in Russian).
} 
rable as per age $(p=0.068)$, sex $(p=0.149)$, and working experience under adverse working conditions $(\mathrm{p}=0.201)$.

We analyzed prevalence of metabolic disorders, $\mathrm{AH}$, and changes in external breath function (EBF) depending on length of working experience under adverse occupational conditions for workers from the test group. We examined frequency of fat, carbohydrate, and lipid metabolism disorders, $\mathrm{AH}$, as well as EBF parameters for workers distributed into subgroups as per working experience starting from one not exceeding 5 years; from 6 to 10 years; from 11 to 20 years; from 21 to 30 years; from 31 to 40 years; longer than 40 years.

Then we analyzed case histories of 172 workers employed at refractory production who had been examined at the clinic in 2000-2017. The basic group included 75 patients with diagnosed silicosis and the reference group was made up of 97 workers with long working experience who didn't have occupational diseases diagnosed during the PME accomplished at the $1^{\text {st }}$ stage. Both groups were comparable as per sex $(p=0.052)$ and working experience under exposure to dust $(21.11 \pm 1.03$ and $20.85 \pm 1.05$ years accordingly, $\mathrm{p}=0.862$ ). Workers from the basic group were older $(55.84 \pm 0.96$ and $49.72 \pm 0.84$ accordingly, $\mathrm{p}=0.000$ ). Average concentration of crystalline silicon oxide dust over a shift in working area air amounted to $3.19 \pm 0.26 \mathrm{mg} / \mathrm{m}^{3}$ for workers from the basic group and to $1.87 \pm 0.12 \mathrm{mg} / \mathrm{m}^{3}$ for workers from the reference one. We analyzed prevalence of cardiovascular pathology and risk factors that could cause it among workers employed at refractory production; we also analyzed influence exerted by cardiovascular pathology on silicosis occurrence.

To perform mathematic analysis, we used SPSS applied software (version 20) [17, 18].

Results and discussion. Only 25 workers $(5.57 \%)$ among those employed at refractory production and examined during the PME didn't have any changes in their somatic health. $\mathrm{AH}$ was diagnosed in 90 workers from the examined group $(20 \%)$. There were no ischemic heart disease cases in the group. 9 people (2\%) had type-2 diabetes and there was high prevalence of hyperglycemia as 90 workers $(20 \%)$ had elevated dextrose level in their blood on empty stomach. It should be noted that practically half of workers (216 people or $48.1 \%$ ) had elevated levels of total cholesterol (TC) in their blood.

On average workers in the group tended to have increased body mass index (BMI) that amounted to $26.43 \pm 0.23 \mathrm{~kg} / \mathrm{m}^{2}$ (from 17.7 to 49.1). Only 112 people $(24.9 \%)$ had normal weight. 337 people $(75.1 \%)$ had their BMI deviating from the physiological standard. 167 people $(37.2 \%)$ had overweight and 170 people $(37.9 \%)$ had obesity with different manifestation. Therefore, more than a half of the examined workers had overweight.

Having compared workers from subgroups with working experience not exceeding 5 years and from 6 to 10 years, we revealed a significant decrease in all EBF parameters in patients with their working experience being from 6 to 10 years, as well as a significant increase in total cholesterol (TC) contents in blood $(p=0.012)$ and dextrose in blood $(p=0.016)$, an authentic increase in number of cases when there were elevated TC contents in blood $(p=0.018)$ and dextrose in blood on empty stomach $(p=0.021)$. Having compared sub-groups with working experience being from 6 to 10 years and from 11 to 20 years, we revealed not only a significant difference in age but also an authentic increase in average BMI value, from $25.60 \pm 0.44 \mathrm{~kg} / \mathrm{m}^{2}$ to $26.89 \pm 0.39 \mathrm{~kg} / \mathrm{m}^{2}(\mathrm{p}=0.038)$. Besides, there was a considerable growth in number of $\mathrm{AH}$ cases, from $13 \%$ to $21 \%(p=0.113)$. There was no dynamics in EBF parameters detected when these two sub-groups were compared. Next, we compared sub-groups with working experience being 21-30 years and 31-40 years; apart from difference in age, there was a significant decrease in such EBF parameters as lung capacity $(\mathrm{LC})(\mathrm{p}=0.013)$ and forced expiratory volume (FEV) during the $1^{\text {st }}$ second $(p=0.034)$; it could mean there were mixed (restrictive and obstructive) disorders in breathing mechanics. That is, workers who were exposed to silicon dioxide dust already had a de- 
crease in their EBF parameters even when their working experience hadn't yet reached 10 years. During the following 10 years (a subgroup with working experience 11-20 years) there was a significant increase in dextrose contents in blood, BMI, and a number of workers with obesity.

172 workers employed at refractory production had more profound examination at the clinic where prevalence of cardiovascular and metabolic pathology was considered. AH was authentically more frequently detected among patients with silicosis $(65 \%$ and $43 \%$ accordingly, $p=0.005)$. Besides, patients with silicosis had cardiac muscle hypertrophy in the left ventricle authentically more frequently, $48 \%$ and $20 \%$, accordingly $(\mathrm{p}=0.002)$; the same was true for ischemic heart disease $(20 \%$ and $7 \%$ accordingly, $\mathrm{p}=0.010$ ), heart rhyme disorders (15\% and $1 \%$ accordingly, $\mathrm{p}=0.006)$, and chronic heart failure $(25 \%$ and $2 \%$ accordingly, $p=0.000)$. Also patients with silicosis had hemoglobin levels in their blood lower than reference values authentically more frequently $(21 \%$ and $8 \%$, accordingly, $\mathrm{p}=0.022$ ).

Having compared time of respiratory pathology occurrence, we revealed that occupational lung fibrosis occurred authentically earlier in patients with stage-3 $\mathrm{AH}$ in comparison with other patients. Thus, median working experience prior to a moment when silicosis was diagnosed amounted to 31.64 years for workers without stage-3 $\mathrm{AH}$ and to 22.7 years for workers with stage- $3 \mathrm{AH}(\mathrm{p}=0.047)$.

In case there were heart rhyme disorders, dust pathology also occurred significantly earlier as median working experience prior to a moment when silicosis was diagnosed amounted to 18.0 years for patients with arrhythmia and to 34.0 years for those without it $(\mathrm{p}=0.011)$.

Silicosis occurred authentically earlier among patients with low hemoglobin; thus, media working experience prior to a moment when silicosis was diagnosed amounted to 31.65 years among patients with normal hemoglobin and to 20.23 among those with low hemoglobin $(p=0.044)$. Besides we revealed certain gender-related differences in silicosis occurrence. Thus, median working experience under exposure to dust prior to silicosis was diagnosed amounted to 33.06 years for men and to 22.27 for women $(\mathrm{p}=0.008)$.

As PME were usually performed on workers without any occupational diseases, it provided an opportunity to detect primary health disorders in them which in future could exert their influence on occupational pathology occurrence. High prevalence of lipid metabolism disorders is rather alerting as they were detected in 216 workers $(48.1 \%)$ and it is significantly higher than on average in the country [19].

Individual reactions a body might have as a response to the same exposure to dust can be due to impacts exerted by regulatory systems, in particular, due to prevalence of sympathotonic or parasympathotonic influence exerted by the vegetative nervous system and due to a ratio between pro- and antiinflammatory hormones produced by the adrenal cortex. This factor can also explain more rapid silicosis occurrence in patients with grave $\mathrm{AH}$ and hypertrophy in the left ventricle detected in our research.

Detected gender-related differences in silicosis occurrence do not contradict literature data. Thus, basing on multi-factor analysis of results obtained via examining workers employed at fire-clay silica refractory production, the authors showed that a female body was more susceptible to silicosis [20].

We can assume that metabolic disorders already existing in a body potentiate chronic systemic inflammation caused by exposure to fibrogenic dust and in future it leads to more rapid silicosis development in patients with somatic pathologies.

\section{Conclusion.}

1. We determined somatic pathologies in workers employed at refractory production that had significant influence on overall and occupational health. As per data obtained via PME workers most frequently had obesity (up to $68 \%$ ). Arterial hypertension prevalence amounted to $19.5 \%$; hypercholesterolemia was detected in $48.1 \%$ cases; and carbohy- 
drate metabolism disorders were detected in $19.8 \%$ cases.

2. Workers employed at refractory production with their working experience being less than 10 years already had a significant decrease in EBF parameters. Besides, as working experience at refractory production grew longer, a significant increase in average BMI occurred $(p=0.025)$, average dextrose contents in blood also grew $(\mathrm{p}=0.045)$, and obesity became more frequent $(p=0.041)$. Therefore, there is a necessity to adjust these factors associated with occupational and somatic diseases occurrence for workers with different working experience under adverse working conditions.

3. Patients with silicosis more frequently suffered from $\mathrm{AH}$, hypertrophy in the left ventricle, IHD, heart rhyme disorders as well as mixed (obstructive and restrictive) breath disorders in comparison with workers with long working experience who didn't have this occupational pathology.
4. We revealed gender-related differences in occupational lung silicosis occurrence among workers employed at refractory production: silicosis occurrence was expected to occur significantly earlier (by 10.8 years) among women in comparison with men.

5. Concomitant somatic pathology authentically influences time in which an occupational pathology occurs: silicosis occurs much earlier due to grave AH (by 11.5 years), arrhythmia (by 13 years), and low hemoglobin (by 11.5 years). Therefore, active prevention and treatment of somatic pathology will make for occupational diseases prevention.

Funding. The research work was accomplished due to financial support provided according to the RF Government Order No. 211, Grant No. 02.A03.21.0006.

Conflict of interests. The authors declare there is no any conflict of interests.

\section{References}

1. Shpagina L.A., Poteryaeva E.L., Kotova O.S., Shpagin I.S., Smirnova E.L. Topical problems of pulmonology in contemporary occupational medicine. Meditsina truda i promyshlennaya ekologiya, 2015, no. 9, pp. 11-14 (in Russian).

2. Velichkovskii B.T. Ekologicheskaya pul'monologiya. Rol' svobodnoradikal'nykh protsessov [Ecologic pulmonology. Role played by free radical processes]. Ekaterinburg, 2003, 140 p. (in Russian).

3. Kuz'mina L.P. Biochemical and molecular mechanisms of occurrence of occupational bronchopulmonary pathology. Pul'monologiya, 2008, no. 4, pp. 107-110 (in Russian).

4. Velichkovskii B.T. Pathogenesis and classification of dust diseases. Meditsina truda i promyshlennaya ekologiya, 2003, no. 7, pp. 1-13 (in Russian).

5. Bugaeva M.S., Mikhailova N.N., Bondarev O.I., Zhdanova N.N. Peculiarities of the structural collagen disorganization as a trigger mechanism of pneumosclerosis in miners. Meditsina truda i promyshlennaya ekologiya, 2018, no. 6, pp. 43-48 (in Russian).

6. Loshchilov Yu.A. Clinical morphology of pneumoconiosis. Arkhiv patologii, 1998, no. 2, pp. 5-31 (in Russian).

7. Loshchilov Yu.A. Contemporary clinical morphology methods in occupational pulmonology. Meditsina truda i promyshlennaya ekologiya, 2008, no. 9, pp. 1-5 (in Russian).

8. Mikhailova N.N., Sazontova T.G., Alekhina D.A., Kazitskaya A.S., Zhdanova N.N., Prokop'ev Yu.A., Zhukova A.G. Features of intracellular protective mechanisms under the action of various xenobiotics on the body. Tsitokiny i vospalenie, 2013, vol. 4, no. 12, pp. 71-75 (in Russian).

9. Vallyathan V., Goins M., Leroy N.L., Pack D., Leonard S., Shi X. Changes in bronchoalveolar lavage indices associated with radiographic classification in coal miners. Am. J. Respiratory and Critical Care Med, 2000, vol. 162, pp. 958-965. DOI: 10.1164/ajrccm.162.3.9909074

10. Shkurupii V.A., Nadev A.P., Karpov M.A. Evaluation of destructive and reparative processes in the liver in experimental chronic granulomatosis of mixed (silicotic and tuberculous) etiology. Byulleten' eksperimental'noi biologii i meditsiny, 2010, no. 6, pp. 622-626 (in Russian).

11. Ghahramani N. Silica nephropathy. Int. J. Occup. Environm. Med, 2010, vol. 1, pp. 108-115 (in Russian). 
12. Cherkasova N.G., Kirilin A.V. Predicting the risk of development of occupational diseases among workers of LLC «LPZ Segal». Aktual'nye problemy aviatsii i kosmonavtiki, 2017, vol. 2, no. 13, pp. 710-712 (in Russian).

13. Shal'nova S.A., Deev A.D., Balanova Yu.A. Kapustina A.V., Imaeva A.E., Muromtseva G.A., Kiseleva N.V., Boitsov S.A. Twenty years trends of obesity and arterial hypertension and their association in Russia. Kardiovaskulyarnaya terapiya i profilaktika, 2017, no. 4, pp. 4-10 (in Russian).

14. Dedov I.I., Shestakova M.V., Galstyan G.R. The prevalence of type 2 diabetes mellitus in the adult population of Russia (NATION study). Sakharnyi diabet, 2016, vol. 19, no. 2, pp. 104-112 (in Russian). DOI: 10.14341/DM2004116-17

15. Rotar O.B., Boyarinova M., Orlov A., Solntsev V., Zhernakova Y., Shalnova S., Deev A., Konradi A. [et al.]. Metabolically healthy obese and metabolically unhealthy non-obese phenotypes in a Russian population. Eur. J. Epidemiol, 2017, vol. 3, pp. 251-254. DOI: 10.1007/s10654-016-0221-z

16. Catapano A.L., Graham I., De Backer G. 2016 ESC/EAS. Guidelines for the Management of Dyslipidaemias. Task Force Members; Additional Contributor. Eur. Heart J., 2016, vol. 37, no. 39, pp. 2999-3058. DOI: 10.1093/eurheartj/ehw272

17. Byuyul' A., Tsefel' P. SPSS: iskusstvo obrabotki informatsii. Analiz statisticheskikh dannykh i vosstanovlenie skrytykh zakonomernostei [SPSS: an art of information processing. Statistical data analysis and hidden regularities recovery]. SPb., OOO «DiaSoftYuP» Publ., 2002, 608 p. (in Russian).

18. Byuyul' A., Tsefel' P. Metody SPSS dlya issledovaniya rynka i mnenii [SPSS techniques for market and opinion research]. Myunkhen, 2000, 608 p. (in Russian).

19. Akhmedzhanov N.M., Nebieridze D.V., Safaryan A.S., Vygodin V.A., Shuraev A.Yu., Tkacheva O.N., Lishuta A.S. Analysis of hypercholesterolemia prevalence in the outpatient practice (according to the argo study): part I. Ratsional'naya farmakoterapiya $v$ kardiologii, 2015, vol. 11, no. 3, pp. 253-260 (in Russian).

20. Katsnel'son B.A., Alekseeva O.G., Privalova L.I., Polzik E.V. Pnevmokoniozy: patogenez i biologicheskaya profilaktika [Pneumoconiosis: pathogenesis and biological prevention]. Ekaterinburg, 1995, 327 p. (in Russian).

Obukhova T.Yu., Budkar' L.N., Gurvich V.B., Solodushkin S.I., Shmonina O.G., Karpova E.A. Influence exerted by somatic pathology on risks of occupational lung fibrosis in workers employed at refractory production. Health Risk Analysis, 2020, no. 3, pp. 124-130. DOI: 10.21668/health.risk/2020.3.15.eng

Received: 18.06 .2020

Accepted: 01.09.2020

Published: 30.09 .2020 